J. Clin. Chem. Clin. Biochem.

Vol. 24, 1986, pp. 341-346

(C) 1986 Walter de Gruyter \& Co.

Berlin - New York

\title{
Simplified and Rapid Methods for the Determination of Protein, Fat and Lactose in Human Milk and the Energy Intake by the Breast-Fed Infant
}

\author{
By F. E. A. M. Verheul, M. J. A. v. d. Bosch, P. J. H. C. Cornelissen
}

Department of Clinical Chemistry and

\section{J. J. J. Waelkens}

Department of Pediatrics

Catharina Hospital, Eindhoven, The Netherlands

(Received October 3, 1985)

Summary: Triacylglycerides constitute the bulk of fat in human milk. By centrifuging the milk a layer of fat is obtained, the cream, the fraction of which correlates very well with the total triacylglyceride concentration. It is determined in analogy to the haematocrit and is called galactocrit ${ }^{1}$ ). Protein is determined with the biuret method in defatted milk. The interference due to lactose in this assay is on average $2 \mathrm{~g} / \mathrm{l}$. Lactose is determined with an enzyme kit. The amount of macronutrients in milk determines the energy value. A protocol is proposed, which makes it possible to measure the quantity of human milk drunk by the infant and to calculate the daily energy intake.

Vereinfachte und schnelle Methode zur Bestimmung von Eiweiß, Fett und Lactose in der Milch vom Menschen sowie der Energieaufnahme brustgenährter Kinder

Zusammenfassung: Triacylglyceride stellen den überwiegenden Teil des Milchfetts dar. Durch Zentrifugation der Milch wird eine Fettschicht, der Rahm, erhalten. Sein Anteil korreliert sehr gut mit der Gesamtkonzentration der Triạcylglyceride. Er wird analog dem Hämatokrit bestimmt und Galaktokrit ${ }^{1}$ ) genannt. Eiweiß wird in der entfetteten Milch mit der Biuret-Methode bestimmt. Die durch Lactose bedingte Interferenz bei dieser Methode beträgt im Mittel $2 \mathrm{~g} / 1$. Lactose wurde mit einem enzymatischen Testbesteck bestimmt. Die Menge an Hauptnährstoffen in der Milch bestimmt ihren Energiegehalt. Es wird ein Protokoll vorgeschlagen, das die Bestimmung der vom Kind getrunkenen Muttermilch und die Berechnung der täglichen Energieaufnahme erlaubt.

1) Footnote (by the Managing Editor*).

Lucas et al. (1. c. (13)) introduced the term creamatocrit which was also used by Lemons et al. (1. c. (18)).

This term was compiled analogously to haematocrit. Haematocrit is made up of two pure Greek components: "Haima" (genetive "haimatos") meaning blood and "krinein" meaning to separate, i. e. blood into cell layer and cell-free layer.

English and Greek components should not be mixed to create a new term.

In the present case milk is separated into cream layer and creamfree layer.
In analogy to haematocrit the term galactocrit is to be preferred, composed of "gala" (genetive "galaktos") meaning milk and "krinein" meaning to separate, i. e. milk into cream layer and cream-free layer.

It should however be mentioned, that apart from fat globules human milk also contains cells, mainly macrophages and polymorphonuclear leukocytes (Faith et al. (1979) Acta Paediatr. Scand. $68,389-396)$.

*) The communication of references and the critical and careful discussion of this footnote by the authors is gratefully acknowledged. 


\section{Introduction}

The resurgence of public interest in human milk as the most adequate source of food for newborn infants is reflected in a rising number of articles on this topic. The question of whether human milk is the ideal formula for the preterm or term infant can only be answered by analysing the composition of the milk. In the past, methods for determining gross composition of bovine milk were used without hardly any modification for human milk. Protein was determined by the Kjeldahl procedure and calculated as total $\mathrm{N} \times 6.38$ (1). Total lipids were determined by time consuming, at present outdated methods $(2,3)$ and lactose was usually determined by methods depending on chemical reduction (1).

In our clinic we were confronted with a prematurely born infant ( 30 weeks gestation, birth weight $1340 \mathrm{~g}$ ) who did not grow sufficiently while being fed with normal quantities of milk from its own mother (4). On analysis it appeared that this milk had a very low protein concentration compared with normal values known from the literature. For this reason, we initiated an investigation into the composition of human milk.

The aim of this study is to present rapid and simple methods for the determination of macronutrients in human milk and to propose a protocol according to which the daily intake of a breast fed infant can be calculated.

\section{Materials and Methods}

\section{Sampling and the calculation of energy intake}

Human milk samples were either obtained at random (for the determination of the relation between the cream layer fraction (galactocrit) and triacylglycerides, and for the biuret assay for human milk protein) or from donations from both breasts according to a protocol which is used in our clinic for at term born infants. Following this protocol, milk is mechanically expressed from both breasts as many times a day as feeds are normally given to the infant during 24 hours. A $3-5 \mathrm{ml}$ sample from each expressed unit is taken for analysis while the remainder of the unit is offered to the infant by means of bottlefeeding. The volume drunk by the infant is measured. Usually 5 to 6 feeds are given during 24 hours. By measuring the volume of the expressed milk, the amount of triacylglycerides, protein and lactose ingested by the infant can be calculated, and any possible correlation with the growth of the infant can be investigated. In addition, the 24-hour composition of human milk can be deduced.

The energy content $(\mathrm{kJ} / \mathrm{l})$ was obtained by multiplying the triacylglyceride concentration $(\mathrm{mmol} / \mathrm{l})$ by $\left.32.6^{2}\right)$, protein $(\mathrm{g} / \mathrm{l})$ $\times 17.9$ and lactose $\left.(\mathrm{g} / \mathrm{l})^{3}\right) \times 16.2$.

\footnotetext{
$\left.{ }^{2}\right)$ Triacylglycerides $(\mathrm{mmol} / \mathrm{l}) \times 0.88$ (molecular mass) $(\mathrm{g} / \mathrm{l})$ $\times 8.87 \frac{\mathrm{kcal}}{\mathrm{g}} \times 4.18 \frac{\mathrm{kJ}}{\mathrm{kcal}}=32.6\left(\frac{\mathrm{kJ}}{\mathrm{l}}\right)$

3) $1 \mathrm{~g} / \mathrm{l}=2,92 \mathrm{mmol} / \mathrm{l}$
}

\section{Determination of the galactocrit}

A sample of human milk, which can be stored at $4^{\circ} \mathrm{C}$ for at least $48 \mathrm{~h}$ after expression, was incubated at $37^{\circ} \mathrm{C}$ (which is above the melting point for human milk fat (5)) and thoroughly mixed. With a haematocrit capillary a small amount of milk was taken (length of milk column about $3 \mathrm{~cm}$ ) and one side of the capillary was sealed. The capillaries were centrifuged in a micro-haematocrit centrifuge at $12000 \mathrm{~g}$ for 15 minutes. The capillaries were placed in a specially designed slide frame and projected. The length of the fat column on top of the milk (a liquid layer of a fat if present was included) related to the entire milk column represented the galactocrit. The galactocrit of a given sample was measured in quadruple.

\section{Determination of lipids in human milk}

Well mixed fresh human milk (100 $\mu$, prewarmed to $\left.37^{\circ} \mathrm{C}\right)$ was reacted with $250 \mu \mathrm{l}$ alkaline ethanol ( $40 \mathrm{~g} \mathrm{KOH}$ in $100 \mathrm{ml}$ $\mathrm{H}_{2} \mathrm{O}$ made up to $1000 \mathrm{ml}$ with ethanol, volume fraction 0.96 ) at $70^{\circ} \mathrm{C}$ for $1 \mathrm{~h}$. After incubation $500 \mu \mathrm{l} 0.15 \mathrm{~mol} / 1 \mathrm{MgSO}_{4}$ was added and the mixture was centrifuged at $3000 \mathrm{~g}$ at room temperature for 10 minutes. The optically clear supernatant was used for the determination of triacylglycerides using a commercial triacylglyceride kit (Bio Mérieux) on a Technicon Random Access Analyser (RA 1000).

Phospholipids were determined as phosphate, after digestion with perchloric acid by the method of Zilversmit \& Davis (6), and extraction by the method of Gentner et al. (7).

Cholesterol was determined after alkaline hydrolysis of cholesterol esters, followed by extraction of the non-saponifiable matter, according to the method of Gentner \& Haasemann (8).

\section{Determination of protein with a modified Kjeldahl} procedure

Total nitrogen in human milk was determined using the Berthelot reaction as described by Meyers \& Rutten (9). Non-protein nitrogen was determined in the clear supernatant which was obtained after addition of $100 \mathrm{~g} / 1$ trichloroacetic acid and centrifugation at $10000 \mathrm{~g}$ and at $4: \mathrm{C}$ for 10 minutes. Protein nitrogen (difference of total and non-protein nitrogen) multiplied by the internationally used factor 6.38 gives the protein concentration of human milk.

Determination of protein in human milk using the biuret reaction

Prior to the determination of protein using the biuret method and lactose the human milk was defatted by centrifuging a sample of milk upside down in a tightly sealed polypropylene tube at $3000 \mathrm{~g}$ and at $4{ }^{\circ} \mathrm{C}$ for 15 minutes. The defatted milk sample can be stored at $-20^{\circ} \mathrm{C}$ until analysis.

Biuret reagent containing $18 \mathrm{mmol}$ disodium ethylenediaminetetraacetate, $15 \mathrm{mmol} \mathrm{Cu}^{2+}$, and $1 \mathrm{~mol}$ of $\mathrm{NaOH}$ per liter was prepared as described by Chrómy et al. $(10,11)$. A sample of $50 \mu \mathrm{l}$ defatted milk was mixed with $1000 \mu \mathrm{l}$ of the biuret reagent at room temperature and the absorbance was read at $550 \mathrm{~nm}$ after 30 minutes taking into account the interference due to the abundant presence of lactose. The results of the determination of protein in defatted milk using the biuret method were corrected for the galactocrit of the sample and thus expressed in whole milk (protein in whole milk $=$ protein in defatted milk $\times(1-$ galactocrit $))$.

\section{Determination of lactose in human milk}

Lactose was determined in a $1: 100$ dilution of defatted milk with a commercially enzymic test kit (ت̈oehringer Mannheim). 
In this reaction $\alpha-D$-lactose in the presence of $\mathrm{NAD}^{+}$is split by $\beta$-galactosidase into $\alpha$ - $D$-glucose and $\beta$ - $D$-galactose. The latter is oxidised by galactose dehydrogenase. The amount of formed NADH is equivalent to the amount of $a-D$-lactose.

Lactose was expressed in whole milk after correction for the galactocrit.

\section{Statistical methods}

Regression analysis was performed as described in detail by Cornbleet \& Gochman (12). This method takes imprecisions in the measurement of both $x$ and $y$ into account. Regression lines are drawn as a function of the rest-variance.

\section{Results}

A simple and quick micromethod for the estimation of the total fat concentration of human milk has been described by Lucas et al. (13). They correlated the fraction of cream ("creamatocrit") ${ }^{1}$ ) read from a haematocrit capillary tube with the total fat content of a human milk sample. However, their method considers neither the distribution of the lipid classes in human milk, nor the lipid content of the defatted milk. Triacylglycerides are predominant among the lipids comprising up to 0.98 of total lipids (5).

For that reason we investigated the correlation between the galactocrit and the triacylglyceride concentration. We could not obtain a reasonable triacylglyceride assay for human milk with a commercially available enzymic kit using a mixture of lipase and esterase to hydrolyse the triacylglycerides into glycerol. Triacylglycerides and caseins present in human milk in quantities which differ from sample to sample cause turbidity. With the aid of alkaline hydrolysis as described in materials and methods, however, an optically clear solution was obtained which could be easily assayed for glycerol.

Figure 1 shows the correlation between the galactocrit and the triacylglyceride concentration. Thus the galactocrit offers a good estimation of the triacylglyceride concentration. Free glycerol was determined in the ultrafiltrate (cut off $M_{\mathrm{r}} 10000$ ) of defatted milk and was found to be lower than $0.4 \mathrm{mmol} / 1$ (average $0.3 \mathrm{mmol} / \mathrm{l}$ ). This amount can be neglected in relation to the high triacylglyceride concentrations.

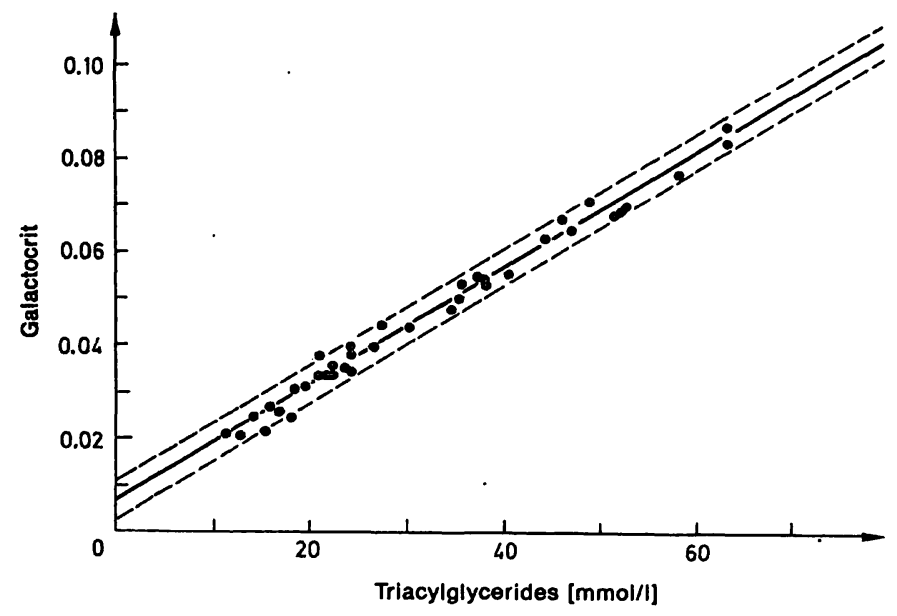

Fig. 1. Correlation between the fraction of the cream layer (galactocrit, determined analogously to the haematocrit) and total triacylglyceride concentration in human milk. Regression equation:

$y=0.125 x+0.659 ; \mathrm{r}=0.994 ; \mathrm{n}=38$

Within run $\mathrm{CV}$ galactocrit:

$3.8 \%$ (mean galactocrit $0.0244, \mathrm{n}=24$ )

$2.2 \%$ (mean galactocrit $0.0540, \mathrm{n}=18$ )

Within run $\mathrm{CV}$ triacylglycerides:

$3.8 \%$ (mean $14.2 \mathrm{mmol} / \mathrm{l}, \mathrm{n}=10$ ).

In order to evaluate the significance of the determination of the galactocrit as an estimation of the total fat content of human milk we also determined triacylglycerides in defatted milk, and cholesterol and phospholipids in whole milk and defatted milk. The results are summarised in table 1 , which shows the predominance of triacylglycerides compared with the much lower concentrations of cholesterol and phospholipids, which agrees with the results of other authors (1, $5,7,14,15)$. The lipid distribution of three 4-hour donations of human milk from three mothers is shown in table 2 . It is apparent that the galactocrit gives a good approximation of the total lipid content of human milk.

The total protein concentration in human milk is traditionally determined by the Kjeldahl method. Although the Kjeldahl method is considered to be an accurate one, it is time consuming because total nitrogen has to be corrected for the non-protein nitrogen content of human milk. It is necessary to correct for

Tab. 1. Lipid content of expressed mature human milk (4 hour donation of mothers of term infants).

\begin{tabular}{lccc}
\hline & Triacylglycerides & Cholesterol & $\begin{array}{c}\text { Phospholipids } \\
\bar{x} \pm \text { SD } \\
(\mathrm{mmol} / \mathrm{l})\end{array}$ \\
\hline Whole milk & $\begin{array}{c}\overline{\mathrm{x}} \pm \mathrm{SD} \\
(\mathrm{mmol} / \mathrm{l})\end{array}$ & $\begin{array}{c}\overline{\mathrm{x}} \pm \mathrm{SD} \\
(\mathrm{mmol} / \mathrm{l})\end{array}$ & $0.45 \pm 0.16$ \\
Defatted milk & $22.9 \pm 5.5$ & $0.80 \pm 0.15$ & $0.28 \pm 0.13$ \\
Defatted milk as fraction of whole milk & $0: 39 \pm 0.18$ & $0.21 \pm 0.04$ & 0.62 \\
Number of samples & 0.02 & 0.26 & 6 \\
\hline
\end{tabular}


Tab. 2. Lipid distribution of three samples (A, B and C) of expressed mature human milk (4 hour donation of mothers of term infants).

\begin{tabular}{|c|c|c|c|c|c|c|c|c|c|}
\hline & \multicolumn{3}{|c|}{$\begin{array}{l}\text { Triacylcerides } \\
(\mathrm{mmol} / \mathrm{l})\end{array}$} & \multicolumn{3}{|c|}{$\begin{array}{l}\text { Cholesterol } \\
(\mathrm{mmol} / \mathrm{l})\end{array}$} & \multicolumn{3}{|c|}{$\begin{array}{l}\text { Phospolipids } \\
\text { (mmol/l) }\end{array}$} \\
\hline & $\mathrm{A}$ & B & C & A & B & C & A & B & $\mathrm{C}$ \\
\hline $\begin{array}{l}\text { Whole milk } \\
\text { Fat globules } \\
\text { Defatted milk }\end{array}$ & $\begin{array}{r}23.6 \\
23.4 \\
0.2\end{array}$ & $\begin{array}{r}22.4 \\
22.3 \\
0.1\end{array}$ & $\begin{array}{r}45.4 \\
44.5 \\
0.9\end{array}$ & $\begin{array}{l}0.8 \\
0.7 \\
0.1\end{array}$ & $\begin{array}{l}0.8 \\
0.5 \\
0.3\end{array}$ & $\begin{array}{l}1.0 \\
0.8 \\
0.2\end{array}$ & $\begin{array}{l}0.4 \\
0.3 \\
0.1\end{array}$ & $\begin{array}{l}0.4 \\
0.1 \\
0.3\end{array}$ & $\begin{array}{l}0.6 \\
0.2 \\
0.4\end{array}$ \\
\hline
\end{tabular}

non-protein nitrogen: in 88 random samples of human milk we found a non-protein nitrogen fraction of $0.221 \pm 0.117$ (mean $\pm 2 \mathrm{SD}$ ), which is much higher than the non-protein nitrogen fraction of $0.04-0.05$ in bovine milk. Thus there is a need for a simple and direct determination of protein in human milk.

The large amount of lipids present in human milk causes turbidity in spectrophotometric assays. Fat globules (the cream), which have been shown to contain the bulk of the lipids, can be easily separated by centrifugation. The Coomassie Brilliant Blue G-250 method as described by Bradford (16) and Johnson \& Lott (17) proved to be unreliable for the determination of protein in human milk, scoring $19.5 \%$ lower than the Kjeldahl method.

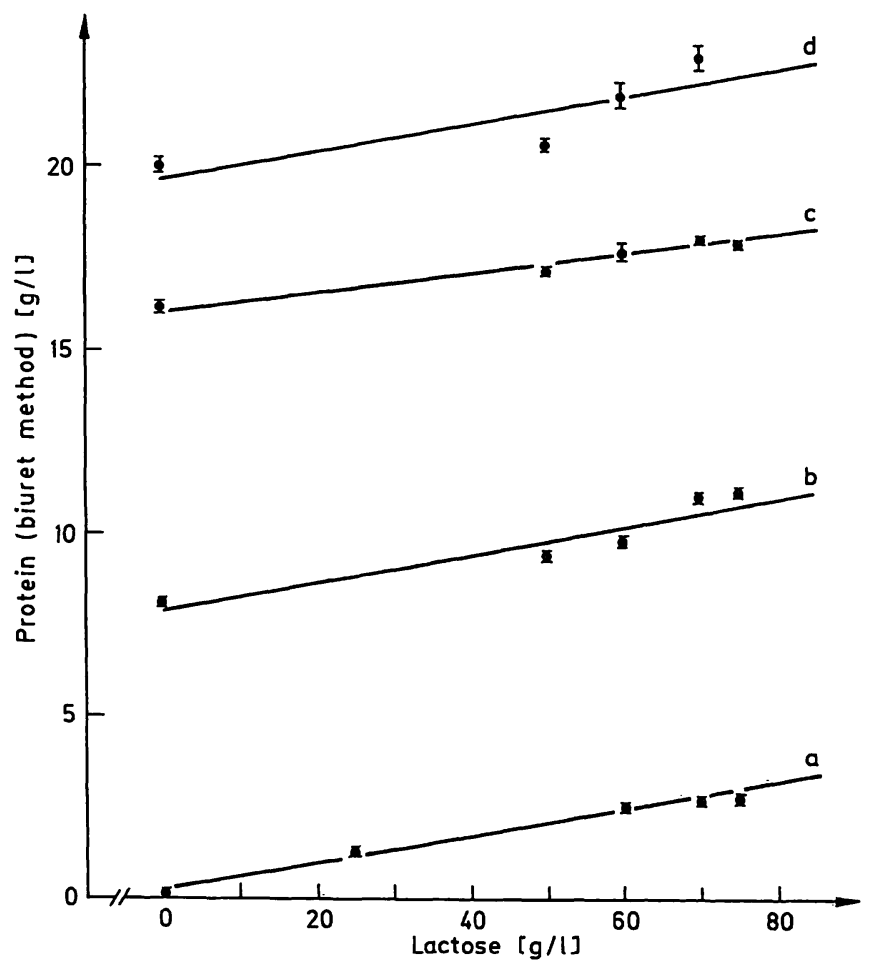

Fig. 2. Lactose interference in the determination of protein standard solutions with increasing lactose concentrations using the biuret reaction ( $n=16$ per datapoint) Line a: no protein (slope 0.035 ); line b: $8 \mathrm{~g} / \mathrm{l}$ protein (slope 0.037); line c: $16 \mathrm{~g} / \mathrm{l}$ protein (slope 0.025) and line d: $20 \mathrm{~g} / \mathrm{l}$ protein (slope 0.034). Mean slope: 0.033 . Lactose interference (reference values of lactose in human milk: $45-75 \mathrm{~g} / 1): 1.5-2.5 \mathrm{~g} / 1$ protein.
We therefore proceeded with the biuret method which is independent of the protein composition. Two methods were tested for the determination of protein in human milk. In the first method defatted milk was deproteinized with $100 \mathrm{~g} / 1$ trichloroacetic acid and the resulting pellet was dissolved in biuret reagent; this method did not give satisfactory results, presumably because trichloroacetic acid does not precipitate all proteins and/or peptides. The second method is a direct one, in which lactose interferes on account of its reducing properties. With standard solutions of lactose and standards containing protein $(50 \mathrm{~g} / \mathrm{l}$ albu$\mathrm{min}$ and $30 \mathrm{~g} / \mathrm{l}$ globulin) and lactose we determined the interference of lactose alone and of lactose in the presence of protein. Figure 2 shows that the lactose interference is $1.5-2.5 \mathrm{~g} / \mathrm{l}$.

The biuret reaction on human milk was compared with a method using the Berthelot reaction (9) (which essentially is a modification of the Kjeldahl procedure). The results are shown in figure 3 . The protein concentration determined with the biuret method is

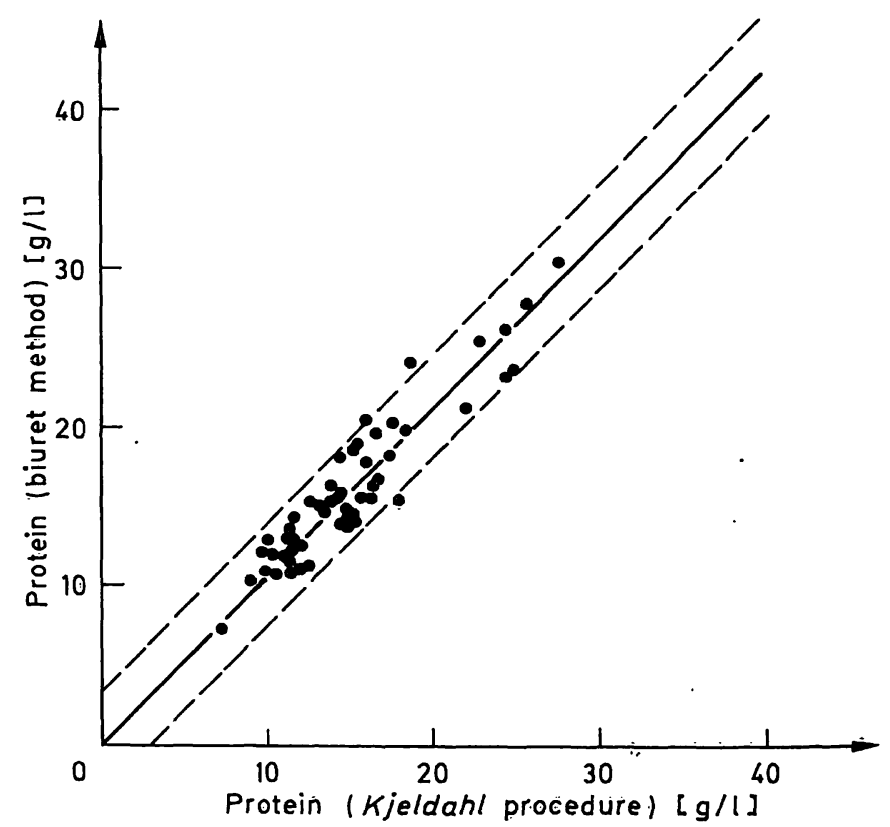

Fig. 3. Correlation between the modified Kjeldahl method and 'the biuret method for determination of protein in human milk. Regression equation: $y=1.066 x+0.085$; $\mathrm{r}=0.947 ; \mathrm{n}=59$. 
about $7 \%$ higher. The day-to-day precision (CV) for the biuret reaction is $2.7 \%$ (within run precision-CV even less than $1 \%$ ) and the day-to-day precision (CV) of the modified Kjeldahl procedure is $8.1 \%$. The higher CV for the Kjeldahl method is partly due to the correction which has to be made for the nonprotein nitrogen. Considering that the modified Kjeldahl procedure suffers from the additional disadvantage that it is more time consuming, we suggest that a simple, rapid and reliable determination of protein in human milk can be achieved with our biuret procedure.

Lactose was determined in a $1: 100$ dilution of defatted milk with an intra run CV of $0.7 \%(n=10$, mean $64 \mathrm{~g} / \mathrm{l})$ and a between run CV of $2.2 \%(\mathrm{n}=8$, mean $64 \mathrm{~g} / 1)$.

Many factors influence the composition of human milk, one of those being the time of the day and the moment a sample is taken during a feed. A typical example is shown in table 3. Apart from the increasing triacylglyceride concentration during a feed, it also shows a difference in triacylglyceride concentration of milk obtained from the right or left breast. It is obvious that random samples of human milk do not give a representative measure of the composition of human milk. For that reason we introduced the protocol as described in materials and methods.

\section{Discussion}

This study shows that the galactocrit correlates very well with the total triacylglyceride concentration. As reported by several authors, triacylglycerides form the major lipid class in human milk $(1,5,7,14,15)$. The galactocrit represents the fraction of microscopic emulsified fat globules in human milk, of which the major proportion are triacylglycerides $(0.96-0.98)$. The galactocrit therefore offers a good approximation of the total lipid concentration, since the lipid content of the defatted milk is negligible.
In contrast with the opinion of Lemons et al. (18) we maintain that a layer of liquid fat, if present, should be included in the cream measurement. This layer of liquid fat contains triacylglycerides with unsaturated fatty acids (especially in colostrum milk) and therefore belongs to the cream.

The triacylglyceride concentration is the major determinant of the energy value. The variability in triacylglyceride concentration among samples from the same mother has already been reported by several authors $(19-22)$. It emphasizes the necessity to base calculations on human milk composition over a 24hour period, in order to avoid miscalculations of energy content.

In the early fifties it was recognized that a considerable proportion (up to 0.25 ) of the total nitrogen in human milk was in the non-protein category $(23,24)$. However, in recent communications some authors persist in reporting protein concentration by multiplying total nitrogen by $6.38(25-27)$. In any case, this factor is subject to considerable variation, as the relative concentrations of the different proteins in human milk changes during lactation. This fact, the time consuming procedure and the high $\mathrm{CV}$ of the Kjeldahl method makes it an inferior method of analysis for the determination of protein in human milk. Neither of these disadvantages accompany the biuret method, which, apart from amino acid analysis, is the method of choice. To avoid disturbance due to lipids the reaction was performed in defatted milk. After correction for the galactocrit and lactose, the results were expressed for whole milk. This is justified since the protein content of the fat globules is negligible (5). There is a difference of $7 \%$ between the biuret and the Kjeldahl method. This difference might be caused by proteins which are not precipitated with trichloroacetic acid.

The importance of a satisfactory collection procedure for human milk is obvious, considering the variability of its nutrients. Based on these considerations many authors have advocated the use of complete 24-hour

Tab. 3. Example of factors influencing the composition of human milk during a day. Samples of milk from a mother of a term infant on $22^{\text {nd }}$ day after birth.

\begin{tabular}{|c|c|c|c|c|c|c|c|}
\hline & & \multicolumn{3}{|c|}{ Right breast } & \multicolumn{3}{|c|}{ Left breast } \\
\hline . & & $\begin{array}{l}\text { Protein } \\
(\mathrm{g} / \mathrm{l})\end{array}$ & $\begin{array}{l}\text { Triacylglycerides } \\
\text { (mmol/1) }\end{array}$ & $\begin{array}{l}\text { Lactose } \\
(\mathrm{g} / \mathrm{l})\end{array}$ & $\begin{array}{l}\text { Protein } \\
(\mathrm{g} / \mathrm{l})\end{array}$ & $\begin{array}{l}\text { Triacylglycerides } \\
(\mathrm{mmol} / \mathrm{l})\end{array}$ & $\begin{array}{l}\text { Lactose } \\
(\mathrm{g} / \mathrm{l})\end{array}$ \\
\hline First feed & $\begin{array}{l}\text { Start } \\
\text { End }\end{array}$ & $\begin{array}{l}10 \\
12\end{array}$ & $\begin{array}{l}23 \\
40\end{array}$ & $\begin{array}{l}58 \\
55\end{array}$ & $\begin{array}{l}11 \\
11\end{array}$ & $\begin{array}{l}33 \\
66\end{array}$ & $\begin{array}{l}59 \\
54\end{array}$ \\
\hline Last Feed & $\begin{array}{l}\text { Start } \\
\text { End }\end{array}$ & $\begin{array}{l}12 \\
11\end{array}$ & $\begin{array}{l}28 \\
43\end{array}$ & $\begin{array}{l}59 \\
57\end{array}$ & $\begin{array}{l}11 \\
12\end{array}$ & $\begin{array}{l}40 \\
73\end{array}$ & $\begin{array}{l}58 \\
51\end{array}$ \\
\hline
\end{tabular}


expressions $(19,27-30)$. The milk was collected at some intervals during 24 hours and afterwards the milk was well mixed and the volume measured. From an analytical point of view this is a correct method. However, the main disadvantage is that during the collection period the infant delivered at term cannot be breast-fed, which excludes the possibility of calculating the energy intake from the analytical results and the volume per feed drunk by the infant. The latter can be inferred when using our protocol. We are well aware of the fact that small misreadings can be made in the volumes of the individual expressed units during a day; however, these errors are smaller than those that accompany the estimation of total milk volume by weighing infants before and after feeds during 24 hours (31). Small premature infants are usually tube fed with total 24 hour collections obtained the previous day, which implies a more accurate evaluation.

\section{References}

1. Jenness, R. (1979) Sem. Perinat. 3, 225-239.

2. British Standards Institution (1955) BS 696.

3. Official Methods of Analysis of the Association of Official Analytical Chemists, ed. 11, Washington, 1979, Association of Official Analytical Chemists.

4. Verheul, F. E. A. M., Cornelissen, P. J. H. C. \& Waelkens, J. J. J. (1984) Ned. Tijdschr. Geneesk. 128, 2113-2114.

5. Blanc, B. (1981) Wld. Rev. Nutr. Diet 36, 1-89.

6. Zilversmit, D. B. \& Davis, A. K. (1950) J. Lab. Clin. Med. $35,155$.

7. Gentner, P. R., Bauer, M. \& Dieterich, J. (1981) J. Chromatogr. 206, 200-204.

8. Gentner, P. R. \& Haasemann, A. (1979) Milchwissenschaft $34,344-346$.

9. Meyers, C. A. M. \& Rutten, J. C. J. M. (1969) Clin. Chim. Acta $24,308-310$.

10. Chrómy, V., Fischer, J. \& Kulhánek, V. (1974) Clin. Chem. 20,1362-1363.

11. Chrómy, V. \& Fischer, J. (1977) Clin. Chem. 23, 754-756.

12. Cornbleet, P. J. \& Gochman, N. (1979) Clin. Chem. 25, $432-438$.

13. Lucas, A., Gibbs, J. A. H., Lyster, R. L. J. \& Baum, J. D. (1978) Brit. Med. J. 1, 1018-1020.

14. Jensen, R. G., Hagerty, M. M. \& McMahon, K. E. (1978) Am. J. Clin. Nutr. 31, 990-1016.

15. Jensen, R. G., Clark, R. M. \& Ferris, A. M. (1979) Lipids $15,345-355$.

16. Bradford, M. M. (1976) Anal. Biochem. 72, 248-254.

17. Johnson, J. A. \& Lott, J. A. (1978) Clin. Chem. 24, $1931-1933$
Simple and rapid methods for determination of nutrients in human milk are demanded. They are important to the clinician, and they give lactating women, who may doubt the quality and/or quantity of their milk, the psychological reassurance of their capability to continue breast feeding. is

With the analytical techniques described in this paper we will draft reference values for different well defined groups of lactating women. Further a correlation between the composition of human milk, intake and growth rate and well being of the infant will be made in a longitudinal study.

\section{Acknowledgement}

The authors wish to thank Mrs. Verberne-Verhagen and Mrs. van Brussel, for secretarial assistance.

18. Lemons, J. A., Schreiner, R. L. \& Gresham, E. L. (1980) Pediatrics 66, 626-628.

19. Gross, S. J., Geller, J. \& Tomarelli (1981) Pediatriçs 68, 490-493.

20. Picciano, M. F., Guthrie, H. A. \& Sheehe, D. M. (1978) Clin. Pediat. 17, 359-362.

21. Hall, B. (1979) Am. J. Clin. Nutr. 32, 304-312.

22. Hibberd, C. M., Brooke, O. G., Carter, N. D., Haug, M. \& Harzer, G. (1982) Arch. Dis. Child. 57, 658-662.

23. Morisson, S. D. (1952) In: Human Milk, Yield, Proximate Principles and Inorganic Constituents, Farnham Royal Commonwealth Agricultural Bureaux.

24. Macy, I. G., Kelly, H. J. \& Sloan, R. E. (1953) In: The composition of milks (Revised) Washington, National Academy of Sciences-National Research Council.

25. Fomon, S. J. (1974) In: Infant Nutrition, Saunders, Philadelphia.

26. Gross, S. J. (1983) N. Engl. J. Med. 308, 237-241.

27. Lucas, A. \& Hudson, G. J. (1984) Arch. Dis. Child. 59, $831-836$.

28. Lemons, J. A., Moye, L., Hall, D. \& Simmons, M. (1982) Pediatr. Res. 16, 113-117.

29. Anderson, G. H., Atkinson, S. A. \& Bryan, M. H. (1981) Am. J. Clin. Nutr. 34, 258-265.

30. Guerrini, P., Bosi, G., Chierici, R. \& Fabbri, A. (1981) Early Hum. Dev. 5, 187-194.

31. Whitfield, M. F., Kay, R. \& Stevens, R. (1981) Arch. Dis. Child. 56, 919-921.

Dr. F. E. A. M. Verheul

Department of Clinical Chemistry

Catharina Hospital

Michelangelolaan 2

P. O. Box 1350

NL-5602 ZA Eindhoven 